\title{
Article
}

Fatemah Nawabdin*

\section{Perspectives on Gender Stereotypes: How Did Gender-Based Perceptions Put Hillary Clinton at an Electoral Disadvantage in the 2016 Election?}

https://doi.org/10.1515/spp-2021-0014

Received July 2, 2021; accepted October 28, 2021

\begin{abstract}
Research on gender stereotypes has largely emphasized that women candidates are evaluated differently compared to their male counterparts. In this article, I argue that such differential evaluation put Clinton at an electoral disadvantage in the 2016 election. I develop my expectations based on the differences between feminine stereotypes and masculine stereotypes and how voters' perceptions of the latter match the longstanding popular expectations for political leaders, in a way that advantages men as candidates and disadvantages women. I also expect that a "gender affinity effect" influenced the election, with Democratic women being more likely to vote for Clinton. In this article, I rely on data from the 2016 American National Election Survey to evaluate the role of gender affinity effect and gender stereotypes in Clinton's electability. The results show that masculine personality traits had the largest effect and were more fundamental for winning the White House. They also show that there was no significant evidence of a gender affinity effect among Democratic women in terms of voting for Clinton. These results offer new insights into voters' gender stereotypic perceptions of Clinton and their consequences for the electoral fortunes of women candidates in general.
\end{abstract}

Keywords: gender, voting, American election, masculine, feminine, traits

\section{Introduction}

The 2016 presidential election is considered as one of the landmark events in modern American history for two reasons. First, we witnessed the emergence of the

\footnotetext{
*Corresponding author: Fatemah Nawabdin, PhD Candidate, Kuwait University, Kuwait City,
} Kuwait; and West Virginia University, Morgantown, USA, E-mail: fmn0001@mix.wvu.edu 
first female candidate, Hillary Clinton, as a nominee of a major political party. Second, the result of this election revealed deep divisions by race, gender, and education; though all presidential elections since 1972 have been characterized by such divisions, the 2016 election was the most extreme (Tyson and Maniam 2016). These two facts have led me to raise the following two questions: how did gender affect the outcomes of this election? To what extent did it affect the electability of Clinton in particular?

In this study, I discuss the role that gender played in the 2016 presidential election by exploring perceptions about women in politics. In other words, the purpose of this research is to answer the question: how did voters' perceptions about Hillary Clinton's masculine and feminine traits affect her electability in the 2016 election? The importance of this research question lies in the idea that it highlights the main obstacles to women's leadership in American politics, which previous research has suggested may have significant implications for both policy and political processes (Karpowitz and Mendelberg 2014; Miller 2008) Thus, understanding the obstacles and gender differences in the level of support for a female candidate is necessary to locate the problem and accordingly predict, based on current circumstances, whether the political future of women in the U.S. can change.

To evaluate the role of gender stereotypes in Clinton's electability, I relied on the 2016 American National Election Survey (ANES) data and used two statistical models: logit and OLS regression. The aim of this statistical testing is to determine whether voters' perceptions of Clinton's and Trump's feminine and masculine traits affected their vote, on the one hand, and their feelings toward both candidates, on the other. I found that gender stereotypes advantaged Trump and disadvantaged Clinton, particularly in terms of masculine traits. I also found no evidence for the "gender affinity effect" among female Democrats in terms of voting for Clinton, which was contrary to expectations. In general, the results point to the need to integrate ideas about gender stereotypes and voters' perceptions of these stereotypes to understand what impedes women's political leadership.

Overall, this study is an extension of the existing literature, which focuses on gender stereotypes as a potential cause of bias among voters and on the "gender affinity effect” phenomenon among women voters (Dolan 2008; King and Matland 2003). The primary focus of this article is the U.S. voter behavior in the 2016 presidential election, while its theoretical perspective concerns the differences between feminine and masculine stereotypes and how perceptions of the latter match longstanding popular expectations for political leaders in a way that advantages male and disadvantages female candidates. Men are typically considered tough, decisive, rational, and assertive leaders, while women are thought to be more honest, caring, compassionate, and trustworthy (Alexander and Andersen 1993; 
Burrell 2008; Holman, Merolla, and Zechmeister 2016; Hyde 2014). As mentioned before, people tend to connect political leadership (and more specifically, the presidency) to stereotypically masculine traits (Duerst-Lahti and Kelly 1995; Eagly and Carli 2007; Huddy and Terkildsen 1993a) because leadership and dominance play a powerful role in the practice of this position in a way that disadvantages female candidates. As a result, the central argument of this study is that genderlinked personality traits negatively affected Clinton's political outlook, compromising her chance of winning the 2016 election. However, I also propose that women voters were more likely to support Clinton compared to men voters, which I discuss in greater detail in the following pages.

\section{Literature Review}

\subsection{Gender Stereotypes, Importance of Office, and Vote Choice}

Why people voted the way they did is one of the most interesting questions central to the study of political behavior. Although the answer to this question in the American politics literature varies, it generally revolves around three themes: personal attachments to political parties (See Bartels 2000; Bonneau and Cann 2015; Campbell et al. 1960), issue proximities with candidates (See Abramowitz and Saunders 1998; Miller and Shanks, 1996), and candidates' personal characteristics (See Bartels 2002; Campbell et al. 1960; Hayes 2005). Besides these determinants, there are some other external factors that have been found to have an influence on shaping vote choice in the presidential elections, such as, but not limited to, the state of the economy (See Erikson and Wlezien 2012; Lewis-Beck and Martini 2021). Although the focus of this article is on voters' perceptions of candidates, that does not neglect the importance of the previous mentioned factors in shaping the presidential elections' outcomes. The particular attention given in this article to voters' perceptions of candidates is due to the peculiarity of the 2016 election and its two major candidates. In 2016, Hillary Clinton was the first female candidate to secure the support of a major political party and, despite running against Trump, who lacked political and military experience (See Carey and Lizotte 2017; Pfiffner 2017), she lost the election. My theoretical explanation of this loss is as follows: people tend to see the office of the presidency as a very important office as well as a primarily masculine-coded profession (Conroy 2016; Katz 2016; Kinder 1986; Kinder et al. 1980), and having a female candidate who was trying to win that office triggered negative attitudes toward her, which were conveyed by voting against her. Scholars have always searched for evidence of whether women's lower level of representation is a result of their low interests in politics (supply problem) 
or of straightforward gender bias among voters (demand problem); I argue that the latter type influenced the outcome of the 2016 election. The idea of gender bias is derived from the assumption that people tend to stereotype women politicians as typical women, i.e., warm, kind, and passive, while perceiving men politicians as typical men, i.e., leaders, aggressive, and tough (Alexander and Andersen 1993; Burrell 2008; Carli and Eagly 1999; Holman, Merolla, and Zechmeister 2016; Hyde 2014). Implicit leadership theory posits that people unconsciously choose leaders who display traits of effective leaders (See Rush, Thomas, and Lord 1977; Shondrick, Dinh, and Lord 2010). Traditionally, this picture of effective leader has always been associated with agentic qualities (e.g., competitive, assertive) which are stereotypically masculine (Koenig et al. 2011; Schein 1973; Spence and Buchkner 2000). Consequently, these perceptions disadvantage women politicians as they make them look less qualified for leadership positions; as Huddy and Terkildsen (1993b, 504) stated, "Voters punish candidates who lack typical masculine traits, especially when seeking higher national or executive office.”

The question that should be raised next is: to what extent do gender-based occupational expectations influence women's chances to win the presidency? Historically, women have occupied roles focused on helping others, while men have occupied roles concerned with leadership (Schneider et al. 2015). This division of roles generates gender-based occupational expectations that have been bolstered by socialization. As a result, women have become more likely to adopt communal traits (e.g., warm, kind) that are substantial in caregiving occupations, and men have become more likely to adopt agentic traits (e.g., competitive, decisive) that are fundamental for leadership positions (Eagly, JohannesenSchmidt, and Van Engen 2003). In turn, when a woman nominates herself for a leadership position, such as the presidential office, this will increase prejudice against her following perceived incongruity between people's perceptions of women and their expectation of leaders (Eagly and Karau 2002). I argue that the Democratic Party's presidential nomination of Hillary Clinton in the 2016 election activated this incongruity in people's mind. This is especially the case for two reasons. First, Clinton became the first female nominee of a major political party, which was a strong message for the people that a female candidate might win and become the president of the United States. This raised fears and doubts about the efficiency of Clinton as a female candidate to successfully manage this maledominated position. As the gender-incongruency hypothesis predicts, discrimination against female candidates will occur when people believe that the role stereotype and the person stereotype do not fit (Eagly and Diekman 2005). Second, the importance of the presidential office played a major role in activating voters' gender bias. A significant body of literature suggests that gender stereotypes play a 
more prominent role as the importance of the office increases. Indeed, evidence comes from several sources. It first emerged from studies of presidential character, where scholars found that masculine personality traits are more fundamental for the ideal president than feminine personality traits (Conroy 2016; Katz 2016; Kinder et al. 1980; Kinder 1986). Voters tend to be reluctant to support women for higher positions like those of president and vice president because they perceive them as less capable of managing traditional "male" issues such as war and economy (Mueller 1982). However, the problem is sometimes more complicated because it appears to be caused by party gatekeepers rather than by voters themselves. Some studies have found that stereotyping is stronger in the selection stage and that gatekeepers are more likely to recruit female candidates for gender stereotypical offices (Fox and Oxley 2003). Nevertheless, in the 2016 election, gender bias was not among gatekeepers as much as among voters. The Democratic party's gatekeepers offered Clinton the opportunity to be its nominee, but voters decided not to do so for many reasons, including gender bias. Thus, it may not be surprising that Clinton won the United States Senate elections in 2000 and 2006 and lost the 2016 presidential election. That is, research emphasized that women do no worse than men in lower-level and legislative elections (Huddy and Terkildsen 1993a; McDermott 1997; Smith, Paul, and Paul 2007), but they do much worse in nationallevel and executive office elections such as those for president, governor, and mayor (Burrell 2008; Dolan 2014; Huddy and Terkildsen 1993a; Smith, Paul, and Paul 2007). As Heldman, Carroll, and Olson $(2005,316)$ put it, “There is perhaps no political position where gender stereotypes work more to women's disadvantage than the highly masculinized office of the U.S. presidency."

Another important factor that must be mentioned in this discussion is the fact that candidate gender is not the only cue that voters consider when evaluating candidates running for the presidency. Voters also consider candidate party to build their general expectation. Generally speaking, Americans tend to stereotype political parties in the same way as they stereotype gender. They distinguish between parties based on issue ownerships (Petrocik 1996), which associates some issues such as education and health care with the Democrats and other issues such as military affairs, law, and foreign policy with the Republicans (Pope and Woon 2009). These issue ownerships distinctions have several critical implications. First, they push voters to hold certain beliefs about the candidates within each party (Hayes 2005), even if that belief is untrue. Second, the association of gender traits and party labels harms female Democrat candidates and makes them vulnerable to political campaign's attacks more than any other candidates (Cassese and Holman 2018) in a way that would impede their political success. Therefore, I can conclude that understanding what put Clinton at an electoral disadvantage in the 2016 election requires thinking about all the previous mentioned factors that consider 
gender bias, political party, and the importance of office. Although these factors are not the only determinants that shaped the 2016 election outcome, they played an important role which is what this research aims to test in the empirical part.

\subsection{Gender Affinity Effect}

It is a common assumption that women tend to support female candidates more than men-a phenomenon known as the "gender affinity effect." Indeed, various studies have discussed this phenomenon and explained why it might occur. Some scholars argued that women are more likely to support female candidates because they seek descriptive representation. Mansbridge (1999), for example, emphasized this by pointing to the importance of descriptive representation and how it offers "communicative advantage," which accordingly makes the communication between constituents and their representatives easier and more comfortable. Moreover, past work demonstrates that sometimes, beyond this feeling of gender affinity, is a desire for substantive representation. As some issues such as abortion, and childcare are of greater importance to women voters, they may see female candidates as well-suited to dealing with this type of issues (Herrnson, Lay, and Stokes 2003; Paolino 1995).

Another reason that might explain the gender affinity effect is the interaction of gender and other ideological and partisan orientations. In the contemporary period, women in the United States are more likely than men to lean toward the Democratic party, and at the same time, most of the female candidates who got elected to different offices identify as Democrats; "A total of 366 women have ever been elected or appointed to Congress, including 247 Democrats and 119 Republicans” (Manning and Brudnick 2020, 1). The reality of party-gender overlap in the American elections requires me to address this complexity, which is something I aim to test in the empirical part of this article.

Along with the theoretical explanations, the connection between gender affinity effect and vote choice have been supported empirically (King and Matland 2003; Sanbonmatsu 2002). As Dolan (2008) demonstrated, the relationship between women voters and female candidates can be best explained by the force of shared gender identity and shared party identity. In contrast to most previous studies that were based on hypothetical results, Dolan (2008) utilized real election survey's outcomes derived from the ANES data. The findings showed that women tend to pay more attention to female candidates in their environment and to have warmer feelings toward them. Yet, these positive feelings are primarily dependent on consideration related to political parties; indeed, it appears that women voters have warmer feelings toward female Democratic candidates in particular, and they 
do not have the same positive feelings for female Republican candidates, which suggests that party identity is as central as gender identity in explaining voters' behavior.

Based on the abovementioned research, I can conclude that there are two reasons why I might expect the gender affinity effect to have been present in the 2016 presidential election. First, as previously mentioned, the 2016 election is considered a milestone for Clinton and for women in general. It was the first time in American history that a woman became a nominee of a major political party, which leads us to expect that this event generated a high level of enthusiasm among women voters, pushing them to vote for her. Second, Clinton was a Democratic candidate, which means that she shared gender and party identity with most women voters. Thus, theoretically, we can infer that Clinton was evaluated more positively by women than men and that her primary source of support was Democratic women.

\section{Data and Key Measures}

The key to understanding the public evaluation of female candidates is to look at the data that come from voters who had the opportunity to evaluate them in realworld election situations. The 2016 ANES survey data provide such an opportunity to examine how voters evaluated Clinton and Trump in terms of their masculine and feminine traits in the 2016 presidential election. For many years, the ANES has included a series of questions asking respondents to evaluate each presidential candidate in terms of different traits. I divided those traits into two types: masculine and feminine.

Having outlined my theory in the previous section, I can now introduce my testable hypotheses. To recap, I hypothesize that:

H1: Voters who perceived Clinton positively in terms of masculine and feminine traits were more likely to have warmer feelings toward her.

H2: Voters' positive perceptions of Clinton's masculine traits, rather than of her feminine traits, were more likely to influence voters in voting for her.

H3: Voters who perceived Trump positively in terms of masculine and feminine traits were more likely to have warmer feelings toward him.

H4: Voters' positive perceptions of Trump's masculine traits, rather than of his feminine traits, were more likely to influence voters in voting for him. 
H5: Democratic women were more likely to have positive feelings toward Clinton and to vote for her; there was no gender affinity effect among Republican women.

To measure how voters evaluated Clinton and Trump in terms of masculine traits, first, I built my classification on the existing literature (Alexander and Andersen 1993; Huddy and Capelos 2002; Kahn 1994), where scholars classify traits such as knowledgeable, leader, and calm as masculine. I constructed a multi-item scale that shows evaluations of Clinton based on three masculine traits existing in the data: her knowledge, her leadership skills, and her emotional stability (calm). Evaluations of Clinton on each of these traits were measured on a five-point Likert Scale. The items were then combined to form a mean centered scale. Factor analysis showed a single factor solution, and the resulting scale had a good reliability coefficient $(\alpha=0.86)$. Regarding voters' evaluation of Trump masculine traits, they were measured using the same traits that have been mentioned previously: knowledge, leadership skills, and emotional stability. The items were then combined to form a mean centered scale. Factor analysis showed a single factor solution, and the resulting scale had a good reliability coefficient $(\alpha=0.83)$.

To measure voters' evaluation of Clinton in terms of feminine traits, I also relied on the abovementioned literature, where the scholars classify traits such as caring, honest, and speaks own mind as feminine. I created a multi-item scale that shows voters' evaluation of Clinton and Trump in terms of those traits. As for the masculine traits scale, evaluations of Clinton and Trump on each feminine trait were measured on a five-point Likert Scale. The items were then combined to form a mean centered scale. Factor analysis of Clinton's feminine traits showed a single factor solution, and the resulting scale had a good reliability coefficient $(\alpha=0.84)$. Similarly, the factor analysis of Trump's feminine traits showed a single factor solution, and the resulting scale had an acceptable reliability coefficient $(\alpha=0.71)$.

My first dependent variable is vote choice, which aims to capture for whom voters cast their vote in the 2016 election; thus, it is a discrete variable, where 0 means that they voted for Clinton, and one means that they voted for Trump. It is worthwhile to mention that this variable only includes validated voters; those who self-reported their voting post the election and the ANES validated it. Votes cast for third-party candidates were recoded as missing. The second and third dependent variables are meant to capture voters' feelings toward Clinton and Trump and to what extent they perceive them positively. This might be more useful for parsing out the effects of stereotypes on Clinton and Trump per se from those on party. The feeling thermometer variable is built on a 101-point rating scale, where 0 indicates very cold and negative feelings, and 100 indicates very warm and positive feelings.

To test my fifth hypothesis, I utilize two variables, female and party identification, which will help me to make a gender-party comparison to determine 
whether the gender affinity effect is active among all women or just among those who share the same gender and party identity with Clinton. Therefore, my baseline category is Independent women. Female is a discrete variable that has two values: $0=$ male and $1=$ female. While party identification is a categorical variable that has three categories: one indicates Democrats, two indicates Independents, and three indicates Republicans.

Alongside my main independent variables, I employ a set of control variables that I believe inevitably affect American voters' political behavior: ideology, education, religiosity, age, income, and race. In regard to ideology, it is measured on a seven-point scale where high values mean more conservative. The second control variable is education, which is a categorical variable consisting of six categories, starting with "less than high school" and "ending at a graduate degree"; thus, high values mean a high level of education. The third control variable is the level of religiosity, which is measured by the level of Church attendance. This variable is composed of six numeric categories (0-5), where high values mean high Church attendance. The fourth control variable is age, which takes the values from 18 to 90 , where high values mean older people. Income is divided into 28 categories, where high values mean high income. On the other hand, race is divided into three discrete variables, Black, Hispanic, and other race, where each variable takes two values -0 , which means that the named race does not apply, and 1 , which means that it does-with Whites as the excluded baseline category.

\section{Results}

\subsection{Did Gender and Party Identity Influence People's Perceptions of the Two Candidates?}

First, I provide some descriptive information to illustrate the prevalence of gender and party in influencing people's perceptions of the two candidates in terms of their masculine and feminine traits. As Figure 1 shows, Republican men and women, on average, have similar favorable perceptions of Trump, and there are no significant differences between their ratings of his masculine and feminine traits. An opposite trend is found in Democrats' evaluation of Trump, that is, both Democratic men and women, on average, perceived him negatively in terms of his masculine and feminine traits. Nevertheless, the $F$ test shows that there is a 0.08 difference in the mean results of Democrats' perceptions of Trump's masculine traits, with Democratic women being more likely to evaluate him negatively on this dimension than their male counterparts $(p<0.05)$. 


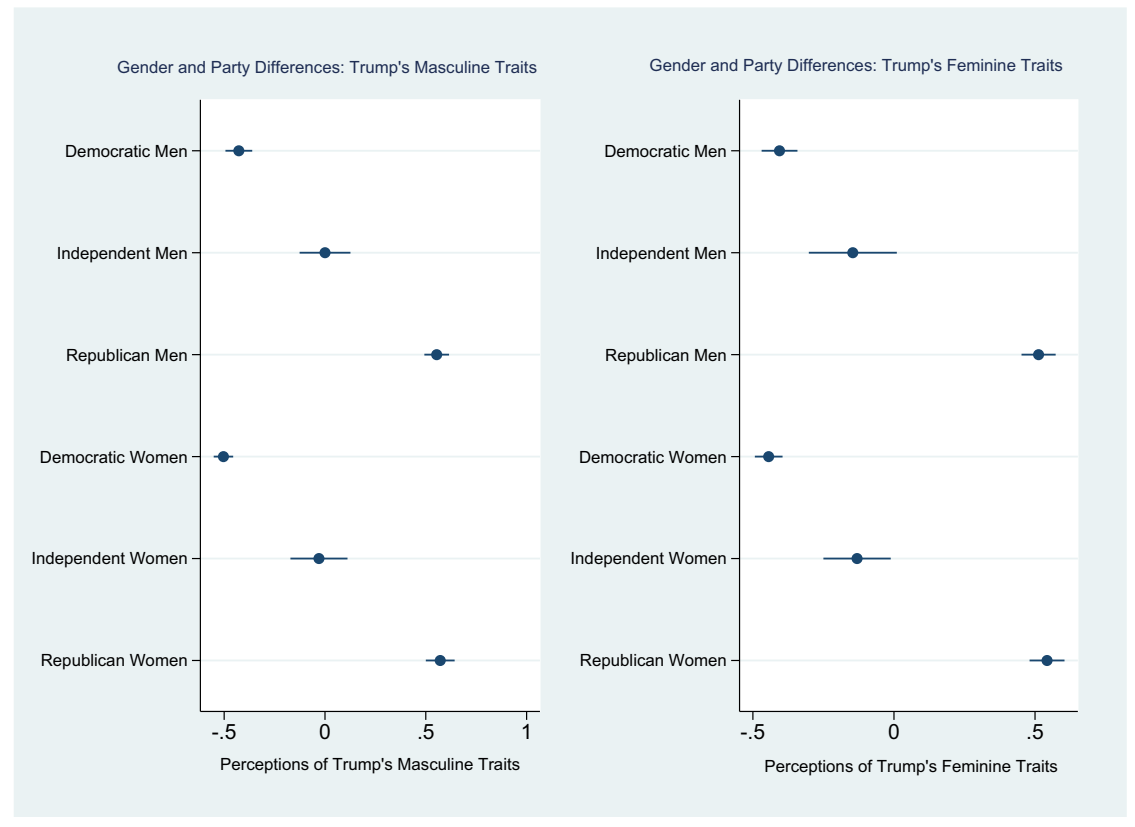

Figure 1: Comparing the differences in means for perceptions of Trump's masculine and feminine traits by party and gender groups.

A further and equally important information to look at emerge from Figure 2 which illustrates that both Republican men and women, on average, evaluated Clinton negatively in terms of her masculine and feminine traits. But the question is, is there any statistically significant difference between the two groups' perceptions? The $F$ test shows that there is a 0.15 difference in the mean results of Republicans' perceptions of Clinton's feminine traits, with Republican men being more likely to evaluate her negatively on this dimension than their female counterparts $(p<0.001)$. This outcome drives me to think about Eagly and Karau's conclusion (2002) that a prejudice exists against female leaders because they are perceived to cause incongruity between the female social role and leadership role. This accordingly might make them more likely to be attacked on their feminine traits, and when attacks focus on feminine traits, female candidates face harsher punishment from voters (See Cassese and Holman 2018). Another important finding emerged from Figure 2 is related to Democratic women's perceptions of Clinton's feminine traits. Both Democratic men and women, on average, perceived her positively in terms of her masculine and feminine traits. Nevertheless, the $F$ test shows that there is a 0.13 difference in the mean results of Democrats' perceptions 

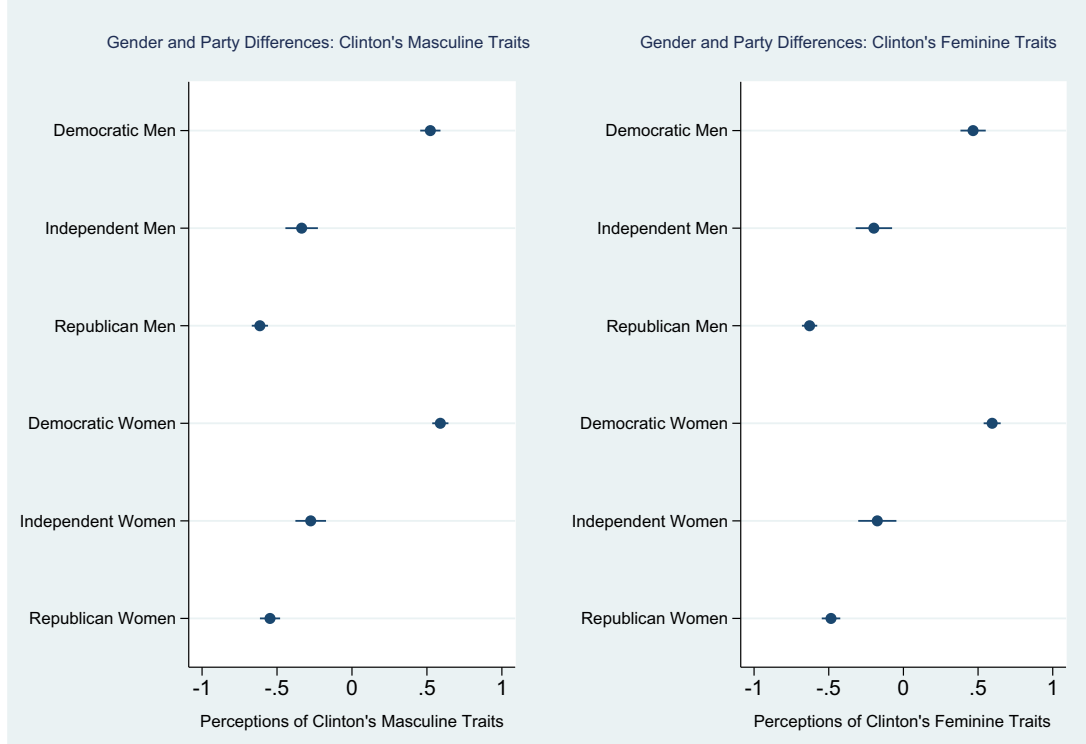

Figure 2: Comparing the differences in means for perceptions of Clinton's masculine and feminine traits by party and gender groups.

of Clinton's feminine traits, with Democratic women being more likely to evaluate her positively on this dimension than their male counterparts $(p<0.05)$. Based on these results, I conclude that, the intersection of gender and party identity shows some interesting variations that open door for further research. Some of the questions that can be raised here is: do women voters prioritize candidates' feminine traits over masculine traits? And does this prioritization differ depending on the gender of the candidate? In fact, these questions are beyond the scope of this article, nevertheless, I raised them here to highlight them for further study.

\subsection{Do Perceptions of Masculine and Feminine Traits Matter?}

To evaluate whether voters' perceptions of Clinton's masculine and feminine traits affected her electability in the 2016 election, I used two statistical models, namely Logit and OLS regression, and investigated two dependent variables: vote choice and voters' feelings toward each candidate. As Table 1 shows, while holding all constant, voters' positive perceptions of Clinton's masculine traits were more 
Table 1: Vote choice and feelings thermometers by perceptions of Candidate's masculine and feminine traits: The 2016 election; logit and OLS regression.

\begin{tabular}{|c|c|c|c|}
\hline & $\begin{array}{r}\text { Vote choice } \\
\text { (logit - odds ratios) }\end{array}$ & $\begin{array}{l}\text { Feelings toward } \\
\text { Trump (OLS) }\end{array}$ & $\begin{array}{r}\text { Feelings toward } \\
\text { Clinton (OLS) }\end{array}$ \\
\hline Perceptions of Trump's & $5.316^{\star \star \star}$ & $15.59^{\star \star \star}$ & $-2.220^{\star \star}$ \\
\hline masculine traits & $(1.28)$ & $(0.77)$ & $(0.75)$ \\
\hline Perceptions of Trump's & $3.119 * \star \star$ & $6.803^{\star \star \star}$ & $-5.006^{\star \star \star}$ \\
\hline feminine traits & $(0.83)$ & $(0.80)$ & $(0.78)$ \\
\hline Perceptions of Clinton's & $0.376^{\star \star \star}$ & 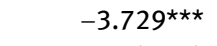 & $8.336^{\star \star \star}$ \\
\hline masculine traits & $(0.08)$ & $(0.75)$ & $(0.73)$ \\
\hline Perceptions of Clinton's & $0.197^{\star \star \star}$ & $-4.223^{\star \star \star}$ & $13.29 * \star \star$ \\
\hline feminine traits & $(0.05)$ & $(0.71)$ & $(0.69)$ \\
\hline \multirow[t]{2}{*}{ Ideology } & $1.884^{\star \star \star}$ & $3.160^{\star \star \star}$ & $-3.129 * \star \star$ \\
\hline & $(0.23)$ & $(0.31)$ & $(0.34)$ \\
\hline \multirow[t]{2}{*}{ Female } & 0.969 & $-1.201^{\star}$ & 0.326 \\
\hline & $(0.24)$ & $(0.65)$ & $(0.70)$ \\
\hline \multirow[t]{2}{*}{ Party identification } & $2.532^{\star \star \star}$ & $5.584^{\star \star \star}$ & $-6.012^{\star \star \star}$ \\
\hline & $(0.36)$ & $(0.63)$ & $(0.61)$ \\
\hline \multirow[t]{2}{*}{ Education } & 0.937 & $-1.310^{\star \star \star}$ & -0.169 \\
\hline & $(0.08)$ & $(0.26)$ & $(0.25)$ \\
\hline \multirow[t]{2}{*}{ Religiosity } & $1.214^{\star}$ & 0.132 & 0.259 \\
\hline & $(0.10)$ & $(0.22)$ & $(0.21)$ \\
\hline \multirow[t]{2}{*}{ Age } & 1.004 & $0.0598^{\star \star}$ & 0.0345 \\
\hline & $(0.01)$ & $(0.02)$ & $(0.02)$ \\
\hline \multirow[t]{2}{*}{ Income } & 0.978 & $-0.160^{\star \star \star}$ & -0.0131 \\
\hline & $(0.02)$ & $(0.05)$ & $(0.05)$ \\
\hline \multirow[t]{2}{*}{ Black } & $0.221^{\star \star}$ & $-3.070^{\star}$ & $7.407^{\star \star \star}$ \\
\hline & $(0.11)$ & $(1.32)$ & (1.28) \\
\hline \multirow[t]{2}{*}{ Hispanic } & $0.344^{\star}$ & $-2.896^{\star}$ & $4.718^{\star \star \star}$ \\
\hline & $(0.16)$ & $(1.37)$ & (1.33) \\
\hline \multirow[t]{2}{*}{ Other } & 0.428 & -0.819 & $4.650^{\star \star \star}$ \\
\hline & $(0.20)$ & $(1.47)$ & (1.42) \\
\hline \multirow[t]{2}{*}{ Constant } & $0.0149 * \star \star$ & $24.74^{\star \star \star}$ & $66.24^{\star \star \star}$ \\
\hline & $(0.01)$ & $(2.18)$ & (2.12) \\
\hline $\mathrm{N}$ & 2284 & 2278 & 2275 \\
\hline Adjusted $R$-squared & & 0.794 & 0.795 \\
\hline
\end{tabular}

Standard errors in parentheses ${ }^{\star} p<0.05,{ }^{\star \star} p<0.01,{ }^{\star \star \star} p<0.001$.

influencing in pushing voters to vote for her compared to their perceptions of her feminine traits. In more details, a unit increase in a voter's positive perceptions of Clinton masculine traits decreases the odds that they voted for Trump by a factor of $0.376(p<0.001)$. On the other hand, a unit increase in a voter's positive perceptions of Clinton feminine traits decreases the odds that they voted for Trump by a 
factor of $0.197(p<0.001)$. I also tested whether voters' perceptions of Trump's masculine and feminine traits affected his chances of winning the election, and as Table 1 illustrates, while holding all constant, voters' positive perceptions of Trump's masculine traits were more influencing in pushing voters to vote for him, compared to their perceptions of his feminine traits. In more details, a unit increase in a voter's positive perceptions of Trump's masculine traits increases the odds that they voted for him by a factor of $5.316(p<0.001)$, while a unit increase in a voter's positive perceptions of Trump feminine traits increases the odds that they voted for him by a factor of $3.119(p<0.001)$.

A further and equally important consideration is the effect of these perceptions on shaping feelings toward each of candidates. The results in Table 1 show that while holding all constant, as perceptions of Clinton's masculine traits increase by one unit, feelings toward her become $8.336^{\circ}$ more positive $(p<0.001)$. Similarly, as perceptions of Clinton's feminine traits increase with a single unit, warmer feelings toward her increase by $13.29^{\circ}(p<0.001)$. On the other hand, when perceptions of Trump's masculine traits increase by one unit, positive feelings toward Clinton decrease by $2.220^{\circ}(p<0.001)$. Further, when perceptions of Trump's feminine traits increase by a single unit, warmer feelings toward Clinton decrease by 5.006 $(p<0.001)$. These results lead us to conclude that perceptions of Clinton's feminine traits had the largest positive effect on her favorability, while perceptions of Trump's feminine traits had the largest negative effect on her favorability.

Perceptions about Trump's masculine and feminine traits, in addition to Clinton's, affected feelings toward him. As Table 1 illustrates, while holding all constant, a unit increase in the level of positive perception about Trump's masculine traits is expected to increase warmer feelings toward him by $15.59^{\circ}$ $(p<0.001)$. Moreover, a unit increase in the level of perception about Trump's feminine traits is also expected to increase positive feelings toward him but at a lower rate of $6.803^{\circ}(p<0.001)$. One the other hand, when perceptions of Clinton's masculine traits increase by one unit, positive feelings toward Trump decrease by $3.729^{\circ}(p<0.001)$; conversely, when perceptions of Clinton's feminine traits increase by a single unit, positive feelings toward Trump decrease by $4.223^{\circ}$ $(p<0.001)$. All in all, I can conclude that perceptions of Trump's masculine traits had the largest effect on his favorability. It is also worthwhile to note that, in contrast to voting choice that is often built on several considerations, most importantly partisanship, feelings toward a candidate help us see the direct effect of stereotypes and analyze it in a way that gives us a comprehensive explanation of the phenomenon. 


\subsection{Gender Affinity Effect, and Voting for Clinton}

Did gender affinity effect play a role in the 2016 presidential election? To evaluate this question, I tested the probability that Democratic women were more likely to have positive feelings toward Clinton and to vote for her and that there was no such effect among Republican women. As mentioned before, Dolan found that women are more likely to vote for women candidates under the effect of gender affinity (Dolan 2008). Yet, this effect is also dependent on identification with the major political parties. The gender-party comparison in Table 2 attempts to draw some conclusion about this effect and its significance in the last election. First, I found

Table 2: Vote choice and feelings thermometer by gender affinity effect; logit and OLS regression.

\begin{tabular}{|c|c|c|c|}
\hline & Vote Choice & Feelings toward Clinton & Feelings toward Trump \\
\hline \multirow[t]{2}{*}{ Female } & 1.458 & 1.467 & -1.45 \\
\hline & $(0.58)$ & (4.89) & $(5.59)$ \\
\hline \multirow[t]{2}{*}{ Republican } & $4.491^{\star \star \star}$ & $-8.150^{\star \star \star}$ & $15.36^{\star \star \star}$ \\
\hline & (1.86) & (3.17) & (3.81) \\
\hline \multirow[t]{2}{*}{ Democrats } & $0.0988^{\star \star \star}$ & $25.91 * \star \star$ & $-18.66^{\star \star \star}$ \\
\hline & $(0.38)$ & $(3.47)$ & $(3.86)$ \\
\hline \multirow[t]{2}{*}{ Republican women } & 0.551 & -2.369 & 0.443 \\
\hline & $(0.29)$ & $(5.16)$ & $(5.86)$ \\
\hline \multirow[t]{2}{*}{ Democratic women } & 0.937 & 1.494 & -1.110 \\
\hline & $(0.47)$ & $(5.31)$ & $(5.78)$ \\
\hline \multirow[t]{2}{*}{ Ideology } & $2.464^{\star \star \star}$ & $-7.254^{\star \star \star}$ & $7.783^{\star \star \star}$ \\
\hline & $(0.08)$ & $(0.57)$ & $(0.61)$ \\
\hline \multirow[t]{2}{*}{ Education } & $0.789^{\star \star}$ & 0.116 & $-2.310^{\star \star \star}$ \\
\hline & $(0.07)$ & $(0.39)$ & $(0.41)$ \\
\hline \multirow[t]{2}{*}{ Religiosity } & 1.080 & 0.675 & -0.287 \\
\hline & $(0.06)$ & $(0.35)$ & $(0.37)$ \\
\hline \multirow[t]{2}{*}{ Age } & 0.997 & $0.153^{\star \star \star}$ & 0.0421 \\
\hline & $(0.01)$ & $(0.03)$ & $(0.04)$ \\
\hline \multirow[t]{2}{*}{ Income } & 0.972 & -0.0526 & $-0.325^{\star \star \star}$ \\
\hline & $(0.01)$ & $(0.09)$ & $(0.09)$ \\
\hline \multirow[t]{2}{*}{ Black } & $0.0472^{\star \star \star}$ & $19.52^{\star \star \star}$ & $-12.62^{\star * *}$ \\
\hline & $(0.02)$ & $(2.35)$ & $(2.44)$ \\
\hline \multirow[t]{2}{*}{ Hispanic } & $0.158^{\star \star \star}$ & $13.24^{\star \star \star}$ & $-8.766^{\star \star \star}$ \\
\hline & $(0.05)$ & $(2.24)$ & $(2.58)$ \\
\hline \multirow[t]{2}{*}{ Other } & $0.441^{\star \star}$ & $7.399 * \star$ & -2.844 \\
\hline & $(0.13)$ & (2.73) & $(2.86)$ \\
\hline \multirow[t]{2}{*}{ Constant } & $0.177^{\star \star}$ & $53.28^{\star \star \star}$ & $28.88^{\star \star \star}$ \\
\hline & $(0.11)$ & (4.63) & (5.15) \\
\hline$N$ & 2907 & 2898 & 2901 \\
\hline Adjusted $R$-squared & & 0.6405 & 0.6122 \\
\hline
\end{tabular}

Standard errors in parentheses ${ }^{\star} p<0.05,{ }^{\star \star} p<0.01,{ }^{\star \star \star} p<0.001$. 
that, while holding all constant, women were more likely to vote for Trump compared to men but this result is not statistically significant. Second, Republican and Democratic women were more likely to vote for Trump compared to Independent women, but this results is not statistically significant. The primary conclusion drawn from these results is that there was no relationship between gender affinity effect and voting for Clinton in the 2016 election.

Along these lines, I also tested whether the gender affinity effect influenced feelings toward both candidates. Findings in Table 2 indicate that, while holding all constant, women were more likely to have positive feelings toward Clinton and negative feelings toward Trump compared to men, but these results are not statistically significant. Findings also show that Democrats average about 26 points higher on the Hillary Clinton thermometer than do Independents $(p<0.001)$, while Republicans average approximately eight points lower than do Independents $(p<0.001)$. On the other hand, Democratic women average about one point higher on the Clinton thermometer than Independent women but these results is not statistically significant, while Republican women average around two points lower than Independent women, and this result is also not statistically significant. Indeed, an opposite pattern is present in the case of feelings toward Trump. As we can see from Table 2, Democrats rate Trump about 18 points lower than Independents $(p<0.001)$, while Republican rate him around 15 points higher than Independents $(p<0.001)$. On the other hand, Democratic women rate Trump around one point lower than Independent women do, but this result is not statistically significant. Based on all these results, I conclude that, although the gender affinity effect was expected to be present in motivating women (and in particular, Democratic women) to vote for Clinton, it was absent and had no significant role in the 2016 election.

All in all, the statistical analysis provides evidence that gender stereotypes played a significant role in the 2016 presidential election. It also shows that perceptions of masculine traits had the largest effect in determining the outcome of that election. Although Clinton achieved the required balance between feminine traits and masculine traits that any women candidates must achieve in order to win (Alexander and Andersen 1993), voter's perceptions of Trump as more "masculine" come at a significant cost for Clinton. Consistent with previous studies, masculine stereotypes were more fundamental in this election because of the importance of the office and the focus on the presidency as masculine-coded profession (Conroy 2016; Katz 2016; Kinder et al. 1980; Kinder 1986). Finally, it seems that gender affinity effect did not have an influential role in pushing women to vote for Clinton in the 2016 election, which can lead us to conclude that there might have been other considerations in that matter. 


\section{Conclusions}

In essence, the well-established tendencies of voters to perceive women candidates as unsuitable for the presidency stem from their stereotypes about men's and women's personality traits. The 2016 election provides us with a real example of how stereotypic assumptions about Clinton's masculine traits were translated into doubts about her ability as a woman to hold such an important office. As my results show, and in line with previous studies, voters' perceptions about each candidate's masculine traits had the greatest effect in determining the winner. An important question that might be raised here is do masculine/feminine traits matter only when studying a presidential race in which a woman runs against a man? What about when a man runs against a man? In fact, I tested this question by looking at the previous presidential elections, in particular, the 2000, 2004, 2008, and 2012 elections; the complete statistical analysis can be found in the Appendix (Tables A1, A2, A3 and A4). The statistical analysis shows that candidates' masculine traits play a significant role in determining vote choice only in the case when the election does not have an incumbent president. I assume when neither of the two nominees are incumbent, voters become more concerned about their leadership skills and whether they have the required masculine traits that make them fit for the office. On the other hand, when one of the nominees is the incumbent president, voters become less worried about his masculine traits because he has been already tested on this aspect during his term. All in all, these assumptions require further research which is beyond the scope of this article.

In the end, this article does not try to state that Clinton's defeat was a result of gender-based stereotypes. It is important to note that Clinton did, in fact, win the popular vote and only lost the electoral vote. So, it might be possible that the negative gender-based perceptions of her - besides other factors - were prevalent in the swing states that actually cost her the presidency. This possibility remains an assumption and it requires further research and test to be supported. Of course, my findings do not suggest that women cannot gain national executive office; in fact, Kamala Harris provided an inspiring example in the 2020 presidential election of what is possible for women to achieve. My findings are only trying to shed a light on gender stereotypes as an influential factor in shaping the outcome of the 2016 election. Although my research does not resolve the causal mechanism between gender stereotypes and the outcome of the election, it does, however, highlight the notion that voters' perceptions about male and female personality traits have a main role in their political behavior. In future research, I plan to supplement my results with cases studies of women running for higher offices who did or did not succeed, to determine whether their electability was affected by gender 
stereotypes. In addition, I could further examine Clinton's history with voters by looking at data from her 2008 bid and evaluate whether gender stereotypes affected her electability, or whether this was caused by something else. I will also analyze how media portrayed Clinton in the 2016 election and to what extent this portrayal was based on gender stereotyping. Examining these cases will allow me to more convincingly argue causality, especially if I could find a consistent pattern among them.

Acknowledgments: The author would like to thank Dr. William Franko (West Virginia University) and Professor Erin Cassese (University of Delaware) for their helpful suggestions; and the anonymous reviewers for their comments on drafts of this manuscript.

\section{Appendix}

Table A1: Vote choice and feelings thermometers by perceptions of candidate's masculine and feminine traits: the 2000 election; logit and OLS regression.

\begin{tabular}{lrrr}
\hline & $\begin{array}{r}\text { Vote choice (logit } \begin{array}{r}\text { Feelings toward } \\
\text { odds ratios) }\end{array} \\
\text { bush (OLS) }\end{array}$ & $\begin{array}{r}\text { Feelings toward } \\
\text { Gore (OLS) }\end{array}$ \\
\hline Perceptions of Bush's & $13.32^{\star \star}$ & $7.86^{\star \star \star}$ & $-4.38^{\star}$ \\
masculine traits & $(11.96)$ & $(1.59)$ & $(1.78)$ \\
Perceptions of Bush's & 4.335 & $10.89^{\star \star \star}$ & 0.75 \\
feminine traits & $(3.50)$ & $(1.63)$ & $(1.82)$ \\
Perceptions of Gore's & 0.433 & 1.88 & $6.25^{\star \star \star}$ \\
masculine traits & $(0.26)$ & $(1.51)$ & $(1.69)$ \\
Perceptions of Gore's & $0.00887^{\star \star \star}$ & $-5.92^{\star \star \star}$ & $12.43^{\star \star \star}$ \\
feminine traits & $(0.01)$ & $(1.62)$ & $(1.80)$ \\
Ideology & 1.580 & $2.00^{\star}$ & -1.99 \\
& $(0.63)$ & $(0.93)$ & $(1.04)$ \\
Female & $15.95^{\star}$ & 0.67 & 3.39 \\
& $(19.42)$ & $(2.92)$ & $(3.28)$ \\
Party identification & $7.332^{\star *}$ & $5.01^{\star \star *}$ & $-3.40^{\star}$ \\
& $(4.61)$ & $(1.39)$ & $(1.56)$ \\
Education & 1.307 & 1.48 & -0.21 \\
& $(0.51)$ & $(0.87)$ & $(0.98)$ \\
Religiosity & 0.853 & -0.36 & -0.09 \\
& $(0.29)$ & $(0.87)$ & $(0.97)$ \\
Age & 1.002 & 0.10 & 0.01 \\
& $(0.02)$ & $(0.06)$ & $(0.07)$ \\
Income & 0.866 & -0.04 & $-0.68^{\star}$ \\
Black & $(0.11)$ & $(0.30)$ & $(0.34)$ \\
& 2.176 & $9.56^{\star}$ & -1.42 \\
& $(2.85)$ & $(3.87)$ & $(4.34)$
\end{tabular}


Table A1: (continued)

\begin{tabular}{lrrr}
\hline & $\begin{array}{r}\text { Vote choice (logit - } \\
\text { odds ratios) }\end{array}$ & $\begin{array}{r}\text { Feelings toward } \\
\text { bush (OLS) }\end{array}$ & $\begin{array}{r}\text { Feelings toward } \\
\text { Gore (OLS) }\end{array}$ \\
\hline Constant & $0.000118^{\star \star}$ & $30.60^{\star \star \star}$ & $76.27^{\star \star \star}$ \\
N & $(0.00)$ & $(5.67)$ & $(6.36)$ \\
Adjusted $R$-squared & 175 & 209 & 210 \\
\hline
\end{tabular}

Standard errors in parentheses ${ }^{\star} p<0.05,{ }^{\star \star} p<0.01,{ }^{\star \star \star} p<0.001$.

Table A2: Vote choice and feelings thermometers by perceptions of candidate's masculine and feminine traits: the 2004 election; logit and OLS regression.

\begin{tabular}{|c|c|c|c|}
\hline & $\begin{array}{r}\text { Vote choice } \\
\text { (logit - odds ratios) }\end{array}$ & $\begin{array}{r}\text { Feelings toward } \\
\text { Bush (OLS) }\end{array}$ & $\begin{array}{r}\text { Feelings toward } \\
\text { Kerry (OLS) }\end{array}$ \\
\hline Perceptions of Bush's & $1.971^{\star \star \star}$ & $11.66^{\star \star \star}$ & $-2.861^{*}$ \\
\hline masculine traits & $(0.52)$ & $(1.30)$ & $(1.21)$ \\
\hline Perceptions of Bush's femi- & $2.435^{\star \star \star}$ & $11.74^{\star \star \star}$ & $-4.226^{\star \star \star}$ \\
\hline nine traits & $(0.55)$ & (1.35) & (1.26) \\
\hline Perceptions of Keriy's & $-1.231^{\star \star}$ & $-2.547^{\star}$ & $6.349^{\star \star \star}$ \\
\hline masculine traits & $(0.48)$ & $(1.20)$ & (1.12) \\
\hline Perceptions of Keriy's & $-2.781^{\star \star \star}$ & $-3.630^{\star *}$ & $11.57^{\star \star \star}$ \\
\hline feminine traits & $(0.62)$ & $(1.14)$ & $(1.06)$ \\
\hline \multirow[t]{2}{*}{ Ideology } & -0.358 & $1.530^{\star}$ & -0.808 \\
\hline & $(0.27)$ & $(0.63)$ & $(0.59)$ \\
\hline \multirow[t]{2}{*}{ Female } & 0.180 & 0.317 & 2.242 \\
\hline & $(0.59)$ & $(1.51)$ & $(1.41)$ \\
\hline \multirow[t]{2}{*}{ Party identification } & -0.0698 & $7.333^{\star \star \star}$ & $-3.292^{\star \star}$ \\
\hline & $(0.23)$ & $(1.12)$ & $(1.05)$ \\
\hline \multirow[t]{2}{*}{ Education } & -0.0393 & 0.480 & $-1.643^{*}$ \\
\hline & $(0.27)$ & $(0.70)$ & $(0.65)$ \\
\hline \multirow[t]{2}{*}{ Religiosity } & -0.0698 & 1.100 & 0.637 \\
\hline & $(0.23)$ & $(0.65)$ & $(0.60)$ \\
\hline \multirow[t]{2}{*}{ Age } & -0.000156 & -0.0235 & $0.135^{\star \star}$ \\
\hline & $(0.02)$ & $(0.05)$ & $(0.04)$ \\
\hline \multirow[t]{2}{*}{ Income } & 0.0980 & -0.00818 & -0.00122 \\
\hline & $(0.06)$ & $(0.13)$ & $(0.12)$ \\
\hline \multirow[t]{2}{*}{ White } & -0.384 & -2.023 & -3.470 \\
\hline & $(0.84)$ & (113) & (1.99) \\
\hline \multirow[t]{2}{*}{ Black } & -0.372 & 2.209 & -1.924 \\
\hline & $(1.08)$ & $(2.71)$ & $(2.53)$ \\
\hline \multirow[t]{2}{*}{ Constant } & -2.048 & $32.67^{\star \star \star}$ & $62.22^{\star \star \star}$ \\
\hline & $(1.83)$ & $(5.17)$ & $(4.84)$ \\
\hline $\mathrm{N}$ & 503 & 503 & 499 \\
\hline Adjusted $R$-squared & & 0.782 & 0.720 \\
\hline
\end{tabular}

Standard errors in parentheses ${ }^{\star} p<0.05,{ }^{\star \star} p<0.01,{ }^{\star \star \star} p<0.001$. 
Table A3: Vote choice and feelings thermometers by perceptions of candidate's masculine and feminine traits: the 2008 election; logit and OLS regression.

\begin{tabular}{|c|c|c|c|}
\hline & $\begin{array}{r}\text { Vote choice } \\
\text { (logit - odds ratios) }\end{array}$ & $\begin{array}{r}\text { Feelings toward } \\
\text { Obama (OLS) }\end{array}$ & $\begin{array}{r}\text { Feelings toward } \\
\text { McCain (OLS) }\end{array}$ \\
\hline $\begin{array}{l}\text { Perceptions of Obama's } \\
\text { masculine traits }\end{array}$ & $\begin{array}{r}4.771^{\star *} \\
(2.34)\end{array}$ & $\begin{array}{r}9.97^{\star \star \star} \\
(1.21)\end{array}$ & $\begin{array}{l}-2.28 \\
(1.27)\end{array}$ \\
\hline $\begin{array}{l}\text { Perceptions of Obama's } \\
\text { feminine traits }\end{array}$ & $\begin{array}{r}3.996^{\star *} \\
(1.74)\end{array}$ & $\begin{array}{r}9.92^{\star * \star} \\
(1.20)\end{array}$ & $\begin{array}{r}-2.83^{*} \\
(1.26)\end{array}$ \\
\hline $\begin{array}{l}\text { Perceptions of McCain's } \\
\text { masculine traits }\end{array}$ & $\begin{array}{l}0.443 \\
(0.22)\end{array}$ & $\begin{array}{l}-2.13 \\
(1.23)\end{array}$ & $\begin{array}{r}6.13^{\star * \star} \\
(1.29)\end{array}$ \\
\hline $\begin{array}{l}\text { Perceptions of McCain's } \\
\text { feminine traits }\end{array}$ & $\begin{array}{r}0.267^{\star \star} \\
(0.12)\end{array}$ & $\begin{array}{l}-2.45 \\
(1.27)\end{array}$ & $\begin{array}{r}8.81^{\star \star \star} \\
(1.33)\end{array}$ \\
\hline Ideology & $\begin{array}{r}0.612^{*} \\
(0.14)\end{array}$ & $\begin{array}{r}-1.70^{\star *} \\
(0.58)\end{array}$ & $\begin{array}{r}0.85 \\
(0.61)\end{array}$ \\
\hline Female & $\begin{array}{l}0.686 \\
(0.39)\end{array}$ & $\begin{array}{r}0.43 \\
(1.61)\end{array}$ & $\begin{array}{r}0.28 \\
(1.70)\end{array}$ \\
\hline Party identification & $\begin{array}{r}0.354^{\star \star} \\
(0.14)\end{array}$ & $\begin{array}{r}-2.73^{\star} \\
(1.22)\end{array}$ & $\begin{array}{r}5.73^{\star \star \star} \\
(1.29)\end{array}$ \\
\hline Education & $\begin{array}{l}1.154 \\
(0.28)\end{array}$ & $\begin{array}{r}0.15 \\
(0.72)\end{array}$ & $\begin{array}{r}0.37 \\
(0.76)\end{array}$ \\
\hline Religiosity & $\begin{array}{l}1.174 \\
(0.27)\end{array}$ & $\begin{array}{l}-1.14 \\
(0.67)\end{array}$ & $\begin{array}{l}1.61^{*} \\
(0.70)\end{array}$ \\
\hline Age & $\begin{array}{l}0.997 \\
(0.02)\end{array}$ & $\begin{array}{r}0.02 \\
(0.05)\end{array}$ & $\begin{array}{l}-0.01 \\
(0.05)\end{array}$ \\
\hline Income & $\begin{array}{l}0.997 \\
(0.05)\end{array}$ & $\begin{array}{l}-0.22 \\
(0.14)\end{array}$ & $\begin{array}{l}-0.06 \\
(0.14)\end{array}$ \\
\hline Black & $\begin{array}{l}10.33^{*} \\
(11.34)\end{array}$ & $\begin{array}{r}7.88^{\star \star \star} \\
(2.28)\end{array}$ & $\begin{array}{r}0.24 \\
(2.41)\end{array}$ \\
\hline Hispanic & $\begin{array}{l}1.321 \\
(0.99)\end{array}$ & $\begin{array}{r}5.48^{\star \star} \\
(2.07)\end{array}$ & $\begin{array}{r}2.37 \\
(2.18)\end{array}$ \\
\hline Other & $\begin{array}{l}1.520 \\
(1.82)\end{array}$ & $\begin{array}{r}10.81^{\star \star} \\
(3.81)\end{array}$ & $\begin{array}{r}1.21 \\
(3.92)\end{array}$ \\
\hline Constant & $\begin{array}{l}137.1^{\star \star \star} \\
(204.32)\end{array}$ & $\begin{array}{r}76.93^{\star \star \star} \\
(4.51)\end{array}$ & $\begin{array}{r}32.78^{\star \star \star} \\
(4.76)\end{array}$ \\
\hline $\mathrm{N}$ & 351 & 473 & 476 \\
\hline Adjusted $R$-squared & & 0.702 & 0.552 \\
\hline
\end{tabular}

Standard errors in parentheses ${ }^{\star} p<0.05,{ }^{\star \star} p<0.01,{ }^{\star \star \star} p<0.001$. 
Table A4: Vote choice and feelings thermometers by perceptions of candidate's masculine and feminine traits: the 2012 election; logit and OLS regression.

\begin{tabular}{|c|c|c|c|}
\hline & $\begin{array}{r}\text { Vote choice } \\
\text { (logit - odds ratios) }\end{array}$ & $\begin{array}{r}\text { Feelings toward } \\
\text { Obama (OLS) }\end{array}$ & $\begin{array}{r}\text { Feelings toward } \\
\text { McCain (OLS) }\end{array}$ \\
\hline Perceptions of Obama's & $2.577^{\star \star \star}$ & 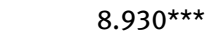 & $-2.630^{\star \star}$ \\
\hline masculine traits & $(0.58)$ & $(0.74)$ & $(0.82)$ \\
\hline Perceptions of Obama's & $8.012^{\star \star \star}$ & $13.31^{\star \star \star}$ & $-4.477^{\star \star \star}$ \\
\hline feminine traits & $(1.91)$ & $(0.74)$ & $(0.83)$ \\
\hline Perceptions of Romney's & $0.306^{\star \star \star}$ & $-3.862^{\star \star \star}$ & $5.815^{\star \star \star}$ \\
\hline masculine traits & $(0.07)$ & $(0.64)$ & $(0.71)$ \\
\hline Perceptions of Romney's & $0.164^{\star \star \star}$ & $-3.975^{\star \star \star}$ & $11.73^{\star \star \star}$ \\
\hline feminine traits & $(0.04)$ & $(0.71)$ & $(0.79)$ \\
\hline \multirow[t]{2}{*}{ Ideology } & $0.681^{\star \star \star}$ & $-1.942^{\star \star \star}$ & $1.096^{\star \star}$ \\
\hline & $(0.08)$ & $(0.30)$ & $(0.33)$ \\
\hline \multirow[t]{2}{*}{ Female } & 0.772 & 0.778 & 1.070 \\
\hline & $(0.18)$ & $(0.68)$ & $(0.76)$ \\
\hline \multirow[t]{2}{*}{ Party identification } & $0.367^{\star \star \star}$ & 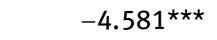 & $4.295^{\star \star \star}$ \\
\hline & $(0.06)$ & $(0.62)$ & $(0.69)$ \\
\hline \multirow[t]{2}{*}{ Education } & 1.100 & -0.379 & -0.378 \\
\hline & $(0.09)$ & $(0.24)$ & $(0.27)$ \\
\hline \multirow[t]{2}{*}{ Religiosity } & 1.072 & -0.341 & -0.447 \\
\hline & $(0.11)$ & $(0.29)$ & $(0.32)$ \\
\hline \multirow[t]{2}{*}{ Age } & 1.008 & -0.00953 & 0.00487 \\
\hline & $(0.01)$ & $(0.02)$ & $(0.02)$ \\
\hline \multirow[t]{2}{*}{ Income } & 0.972 & $-0.126^{\star \star}$ & -0.0539 \\
\hline & $(0.02)$ & $(0.05)$ & $(0.05)$ \\
\hline \multirow[t]{2}{*}{ White } & 0.618 & $-3.775^{\star \star}$ & -0.208 \\
\hline & $(0.27)$ & $(1.43)$ & $(1.60)$ \\
\hline \multirow[t]{2}{*}{ Black } & $4.947^{\star}$ & 0.950 & -1.191 \\
\hline & (3.13) & (1.56) & (1.75) \\
\hline \multirow[t]{2}{*}{ Constant } & $86.67^{\star \star \star}$ & 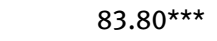 & $36.78^{\star \star \star}$ \\
\hline & $(72.43)$ & $(2.71)$ & (3.02) \\
\hline$N$ & 2247 & 2240 & 2237 \\
\hline Adjusted $R$-squared & & 0.8116 & 0.6778 \\
\hline
\end{tabular}

Standard errors in parentheses ${ }^{\star} p<0.05,{ }^{\star *} p<0.01,{ }^{\star \star \star} p<0.001$.

\section{References}

Abramowitz, A. I., and K. L. Saunders. 1998. "Ideological Realignment in the US Electorate." The Journal of Politics 60 (3): 634-52.

Alexander, D., and K. Andersen. 1993. "Gender as a Factor in the Attribution of Leadership Traits.” Political Research Quarterly 46 (3): 527-45.

Bartels, L. M. 2000. “Partisanship and Voting Behavior, 1952-1996.” American Journal of Political Science 44 (1): 35-50. 
Bartels, L. M. 2002. "Beyond the Running Tally: Partisan Bias in Political Perceptions." Political Behavior 24 (2): 117-50.

Bonneau, C. W., and D. M. Cann. 2015. "Party Identification and Vote Choice in Partisan and Nonpartisan Elections.” Political Behavior 37 (1): 43-66.

Burrell, B. 2008. "Likeable? Effective Commander in Chief? Polling on Candidate Traits in the Year of the Presidential Woman." PS: Political Science and Politics 41 (4): 747-52.

Campbell, A., P. E. Converse, W. E. Miller, and D. E. Stokes. 1960. The American Voter. New York: Wiley.

Carey, T. E., Jr, and M.-K. Lizotte. 2017. "Political Experience and the Intersection between Race and Gender." Politics, Groups, and Identities 7 (2): 1-24.

Carli, L. L., and A. H. Eagly. 1999. "Gender Effects on Social Influence and Emergent Leadership." In Handbook of Gender and Work, 203-22. Thousand Oaks, California: Sage Publications, Inc.

Cassese, E. C., and M. R. Holman. 2018. "Party and Gender Stereotypes in Campaign Attacks." Political Behavior 40 (3): 785-807.

Conroy, M. 2016. Masculinity, Media, and the American Presidency. Springer.

Dolan, K. 2008. "Is There a "Gender Affinity Effect" in American Politics? Information, Affect, and Candidate Sex in US House Elections." Political Research Quarterly 61 (1): 79-89.

Dolan, K. A. 2014. When Does Gender Matter?: Women Candidates and Gender Stereotypes in American Elections. Oxford: Oxford University Press.

Durest-Lahti, G., and M. Kelly. 1995. Gender Power, Leadership and Governance. Ann Arbor: University of Michigan Press.

Eagly, A. H., and L. L. Carli. 2007. Through the Labyrinth: The Truth about How Women Become Leaders. Boston, MA: Harvard Business Press.

Eagly, A. H., and A. B. Diekman. 2005. "What is the problem? Prejudice as an attitude-in-context." In On the Nature of Prejudice: Fifty Years After Allport, edited by J. F. Dovidio, P. Glick, and L. A. Rudman, 19-35. Malden, MA: Blackwell.

Eagly, A. H., and S. J. Karau. 2002. "Role Congruity Theory of Prejudice toward Female Leaders." Psychological Review 109 (3): 573.

Eagly, A. H., M. C. Johannesen-Schmidt, and M. L. Van Engen. 2003. “Transformational, Transactional, and Laissez-Faire Leadership Styles: A Meta-Analysis Comparing Women and Men." Psychological Bulletin 129 (4): 569.

Erikson, R. S., and C. Wlezien. 2012. "The Objective and Subjective Economy and the Presidential Vote." PS: Political Science and Politics 45 (4): 620-4.

Fox, R. L., and Z. M. Oxley. 2003. "Gender Stereotyping in State Executive Elections: Candidate Selection and Success." The Journal of Politics 65 (3): 833-50.

Hayes, D. 2005. "Candidate Qualities Through a Partisan Lens: A Theory of Trait Ownership." American Journal of Political Science 49 (4): 908-23.

Heldman, C., S. J. Carroll, and S. Olson. 2005. ““'She Brought Only a Skirt”: Print Media Coverage of Elizabeth Dole's Bid for the Republican Presidential Nomination." Political Communication 22 (3): 315-35.

Herrnson, P. S., J. Celeste Lay, and A. Kai Stokes. 2003. "Women Running “As Women”: Candidate Gender, Campaign Issues, and Voter-Targeting Strategies." The Journal of Politics 65 (1): 244-55.

Holman, M. R., J. L. Merolla, and E. J. Zechmeister. 2016. "Terrorist Threat, Male Stereotypes, and Candidate Evaluations.” Political Research Quarterly 69 (1): 134-47. 
Huddy, L., and T. Capelos. 2002. "Gender Stereotyping and Candidate Evaluation." In The Social Psychology of Politics, 29-53. Boston: Springer, https://doi.org/10.1007/978-1-4615-0569$3 \_2$.

Huddy, L., and N. Terkildsen. 1993a. "Gender Stereotypes and the Perception of Male and Female Candidates." American Journal of Political Science 37 (1): 119-47.

Huddy, L., and N. Terkildsen. 1993b. "The Consequences of Gender Stereotypes for Women Candidates at Different Levels and Types of Office." Political Research Quarterly 46 (3): 503-25.

Hyde, J. S. 2014. “Gender Similarities and Differences.” Annual Review of Psychology 65: 373-98.

Kahn, K. F. 1994. "Does Gender Make a Difference? an Experimental Examination of Sex Stereotypes and Press Patterns in Statewide Campaigns." American Journal of Political Science 38 (1): 162-95.

Karpowitz, C. F., and T. Mendelberg. 2014. The Silent Sex: Gender, Deliberation, and Institutions. Princeton, NJ: Princeton University Press.

Katz, J. 2016. Man Enough? Donald Trump, Hillary Clinton, and the Politics of Presidential Masculinity. Northampton, MA: Interlink.

Kinder, D. R. 1986. “Presidential Character.” In Political Cognition Revisited, edited by R. R. Lau, and D. O. Sears, 233-55. Hillsdale, NJ: Erlbaum.

Kinder, D. R., D. Mark Peters, P. Robert Abelson, and T. Susan Fiske. 1980. "Presidential Prototypes." Political Behavior 2 (4): 315-37.

King, D. C., and R. E. Matland. 2003. "Sex and the Grand Old Party: An Experimental Investigation of the Effect of Candidate Sex on Support for a Republican Candidate." American Politics Research 31 (6): 595-612.

Koenig, A. M., A. H. Eagly, A. A. Mitchell, and T. Ristikari. 2011. "Are Leader Stereotypes Masculine? A Meta-Analysis of Three Research Paradigms.” Psychological Bulletin 137 (4): 616.

Lewis-Beck, C., and N. F. Martini. 2020. "Economic Perceptions and Voting Behavior in US Presidential Elections." Research and Politics 7 (4): 1-6.

Manning, J. E., and I. Brudnick. 2020. Congressional Research Service: Women in Congress Statistics and Brief Overview. Congressional Research Service. https://crsreports.congress. gov/product/pdf/R/R43244 (accessed January, 2021).

Mansbridge, J. 1999. "Should Blacks Represent Blacks and Women Represent Women? A Contingent 'Yes'." The Journal of Politics 61 (3): 628-57.

McDermott, M. L. 1997. "Voting Cues in Low-Information Elections: Candidate Gender as a Social Information Variable in Contemporary United States Elections." American Journal of Political Science 41 (1): 270-83.

Miller, W. E., J. Merrill Shanks, and R. Y. Shapiro. 1996. The New American Voter. Cambridge: Harvard University Press.

Miller, G. 2008. "Women's Suffrage, Political Responsiveness, and Child Survival in American History." Quarterly Journal of Economics 123 (3): 1287-327.

Mueller, C. 1982. Nurturance and Mastery: Competing Qualifications for Women's Access to High Public Office? Wellesley College, Center for Research on Women.

Paolino, P. 1995. "Group-Salient Issues and Group Representation: Support for Women Candidates in the 1992 Senate Elections." American Journal of Political Science 39 (2): 294-313.

Petrocik, J. R. 1996. "Issue Ownership in Presidential Elections, with a 1980 Case Study.” American Journal of Political Science 40 (3): 825-50.

Pfiffner, J. P. 2017. “The Unusual Presidency of Donald Trump.” Political Insight 8 (2): 9-11. 
Pope, J. C., and J. Woon. 2009. "Measuring Changes in American Party Reputations, 1939-2004." Political Research Quarterly 62 (4): 653-61.

Rush, M. C., J. C. Thomas, and R. G. Lord. 1977. "Implicit Leadership Theory: A Potential Threat to the Internal Validity of Leader Behavior Questionnaires." Organizational Behavior and Human Performance 20 (1): 93-110.

Sanbonmatsu, K. 2002. "Gender Stereotypes and Vote Choice." American Journal of Political Science 46 (1): 20-34.

Schein, V. E. 1973. "The Relationship between Sex Role Stereotypes and Requisite Management Characteristics." Journal of Applied Psychology 57 (2): 95.

Schneider, M. C., M. R. Holman, A. B. Diekman, and T. McAndrew. 2015. "Power, Conflict, and Community: How Gendered Views of Political Power Influence Women's Political Ambition." Political Psychology 37 (4): 515-31.

Shondrick, S. J., J. E. Dinh, and R. G. Lord. 2010. “Developments in Implicit Leadership Theory and Cognitive Science: Applications to Improving Measurement and Understanding Alternatives to Hierarchical Leadership." The Leadership Quarterly 21 (6): 959-78.

Smith, J. L., D. Paul, and R. Paul. 2007. "No Place for a Woman: Evidence for Gender Bias in Evaluations of Presidential Candidates." Basic and Applied Social Psychology 29 (3): 225-33.

Spence, J. T., and C. E. Buckner. 2000. "Instrumental and Expressive Traits, Trait Stereotypes, and Sexist Attitudes What Do They Signify?” Psychology of Women Quarterly 24 (1): 44-62.

Tyson, A., and S. Maniam. 2016. Pew Research Center: behind Trump's Victory: Divisions by Race, Gender, Education. Washington, DC: Pew Research Center. http://www.pewresearch.org/ fact-tank/2016/11/09/behind-trumps-victory-divisions-by-race-gender-education/ (accessed September, 2017). 